\title{
The effect of the kind of Fe chelate on yielding and quality of greenhouse tomato fruits
}

\author{
Piotr Chohura*, Eugeniusz Kotota, Andrzej Komosa
}

\author{
Department of Horticulture \\ Wroclaw University of Environmental and Life Sciences \\ Grunwaldzki Sq. 24A, 50-363 Wrocław, Poland
}

\begin{abstract}
A two-year-greenhouse experiment was designed to investigate the effect of four chelates, differing in percentage of Fe content and the kind of Fe bonding ligand: Fe 8 Forte (EDTA+HEEDTA), Fe 9 Premium (DTPA), Fe 13 Top (EDTA) and Librel Fe DP7 (DTPA), on the yield and fruit quality of the 'Merkury' $\mathrm{F}_{1}$ greenhouse tomato cultivar grown in peat substrate. Each of the tested fertilisers was applied in three different doses in order to reach the level of 50,75 or $100 \mathrm{mg}$ available Fe per $1 \mathrm{dm}^{3}$ of growing medium. In the control treatment the amount of this nutrient was equal to $17.9 \mathrm{mg} \mathrm{dm}^{-3}$. The tomato was cultivated from transplants on benches in the period from the beginning of April to the end of July.

The highest marketable yield of tomato fruits was obtained from plants fertilised with Fe 9 Premium (DTPA), while the lowest was from the treatment with Fe 13 Top (EDTA) chelate. Both of these sources of iron were equally efficient for the early crop yield, which was significantly higher than that of other tested fertilisers. Irrespective of the Fe source, the most favourable dose of this nutrient for marketable and early fruit yield was $50 \mathrm{mg} \mathrm{Fe} \mathrm{dm}{ }^{-3}$. Both tested factors had little effect on fruit composition. The only exception was a significant drop of vitamin $\mathrm{C}$ content in the treatment supplied with Fe 9 Premium and an increment of $\mathrm{Na}$ in the case of Fe 13 Top use. The increase of Fe in the growing medium up to 75 and $100 \mathrm{mg} \mathrm{dm}^{-3}$ adversely affected the amount of $\mathrm{P}$ in tomato fruits.
\end{abstract}

Key words: early yield, fruit composition, iron fertilisation, marketable yield

\section{INTRODUCTION}

Ironions play a number ofimportant functions in plants due to their possibility of changing $\mathrm{Fe}^{+3} / \mathrm{Fe}^{+2}$ valence (Guerinot and Yi 1994). Even a temporary deficiency of this microelement causes a considerable reduction in plant growth and yielding (Fernandez and Ebert 2005). According to Mills and Jones (1997), the recommended iron content for vegetables in their growing medium ranges widely, from 5 to $100 \mathrm{mg}$ $\mathrm{Fe} \mathrm{dm}^{-3}$. The greenhouse tomato is classified in the group of vegetables featuring high nutrition needs as far as iron is concerned (Chohura et al. 2007). The characteristic symptoms of iron deficiency in tomatoes are chlorosis, which usually appears at the base of leaflets on the youngest leaves (Bergman 1992). The problems connected with providing this species with appropriate amounts of iron do not usually result from the lack of iron in a growing medium, but from the transformation of $\mathrm{Fe}$ ions into a form not available to plants or disadvantageous conditions regarding root system functioning. 
The chemical sorption of iron consists of forming colloid ferric hydroxide (Tiffin et al. 1960), which mainly takes place in traditionally cultivated plant with ferric sulphate as a common use source of iron. Chlorosis caused by iron deficiency is most often connected with high $\mathrm{pH}$, iron retrogradation with phosphates and carbonates, lack of oxygen in the rhizosphere, or iron antagonism under the influence of a high concentration of manganese, zinc or copper (Fernandez and Ebert 2005). Therefore, iron chelates have become increasingly popular in plant fertilisation. A characteristic property of chelate compounds is forming lined bonds with metal cations. The latter feature good water solubility, a low dissociation constant value and high durability. In this way, iron ions are protected from retrogradation and remain available for plants. As Schmidt and Steinbach (2000) reported, the durability of such a complex and iron availability for the plant mainly depends on the kind of chelate ligand. In fertilisation the following kinds of ligands are often applied:EDTA(ethylenediaminetetraacetic acid), DTPA (diethylenetriaminepentaacetic acid) or HEEDTA (hydroxyl-2-ethylenediaminetriacetic acid) (Stuart et al. 1991, Alvarez-Fernandez at al. 2005); the study investigated the effect of the kind of a carrier and iron concentration on the yielding and fruit quality of greenhouse tomato grown in a peat substrate.

\section{MATERIAL AND METHODS}

The experiments were conducted in a heated greenhouse. Greenhouse tomatoes of the 'Merkury' $\mathrm{F}_{1}$ cultivar were planted into a $15 \mathrm{~cm}$ layer of peat substrate on benches, with $50 \mathrm{dm}^{3}$ substrate volume per plant. The transplants were planted in a spacing of $0.65 \times 0.5 \mathrm{~m}$, in a density of three plants per $1 \mathrm{~m}^{2}$ of bench. The tomatoes were cultivated from the second 10-days of April to the third 10-days of July and trained for one stem and five trusses. The air temperature was maintained at a level of $20-25^{\circ} \mathrm{C}$ during the day and $16-18^{\circ} \mathrm{C}$ at night. The air humidity was kept between $60-70 \%$ while the growing medium moisture was within $60-65 \%$ of the container water capacity at the seedling stage, $65-70 \%$ at flowering, and $70-75 \%$ at the fruit-developing stage. Peat substrate produced by Hartmann, which was limed with chalk to 5.50 $\mathrm{pH}$, was used as a growing medium. The substrate content of nutrients before transplant plating was standardised to the following recommended values (Komosa 2005): $\mathrm{N}-220, \mathrm{P}-180, \mathrm{~K}-350, \mathrm{Ca}-2000$, $\mathrm{Mg}-200, \mathrm{Mn}-20, \mathrm{Zn}-20, \mathrm{Cu}-5.0, \mathrm{~B}-1.5$ and
Mo $-1.5\left(\mathrm{mg} \mathrm{dm}^{-3}\right)$. In the second 10-days of June, the tomatoes were supplementary fertilised using $5 \mathrm{~g} \mathrm{~N}$ and $10 \mathrm{~g} \mathrm{~K}$ per $1 \mathrm{~m}^{2}$ of growing medium. The experiment was established in two factorial designs, with six plants cultivated on one plot. The first factor involved the chelates differing in percentage content of iron and the kind of ligand $\mathrm{Fe}$ bound into the complex: Fe 8 Forte (EDTA+HEEDTA), Fe 9 Premium (DTPA), Fe 13 Top (EDTA) and Librel Fe DP7 (DTPA). The second factor was iron content in the growing medium, which was established to reach the following levels: 50, 75 and $100 \mathrm{mg} \mathrm{Fe}$ $\mathrm{dm}^{-3}$, while in the control treatment $\mathrm{Fe}$ values were $17.9 \mathrm{Fe} \mathrm{dm}^{-3}$ (after liming the peat). Harvest took place twice a week with grading into the following classes: fruit mean over $6 \mathrm{~cm}$ - grade IA, $4.5-6.0 \mathrm{~cm}$ - IB, 3.5-4.5 cm - grade II and below $3.5 \mathrm{~cm}$ were not classified. Marketable yield contained fruits of grades IA, IB and II, while the early yield consisted of tomatoes obtained during the first three harvests. The assessment of fruit nutritional value involved the determination of dry matter by drying it to a stable weight at $105^{\circ} \mathrm{C}$ and vitamin $\mathrm{C}$ assaying using the Tillman method. Tomato fruits were subjected to phosphorus and magnesium using the spectrophotometric method, as well as potassium, calcium and sodium using the flame photometric method after extraction in $2 \%$ acetic acid. Nitrate nitrogen was analysed using the potentiometric method. The obtained results were subjected to statistic evaluation on the basis of an analysis of variance for a two factorial design at a significance level of $p=0.05$. Data of the iron content in tomato fruits are not included in the paper because the amounts of this nutrient remained below the detection level of our laboratory equipment. On average, the content of $\mathrm{Fe}$ in the edible portion of fully matured fruits may reach the level of 0.3-0.5 mg per $100 \mathrm{~g}$ of fresh weight (Lorenz and Maynard 1988).

\section{RESULTS AND DISCUSSION}

The effect of the examined factors was similar for both years of the experiment (2006-2007) and, therefore, the mean values for the entire period under investigation were presented. On the basis of the data shown in Table 1, it may be possible to state that the most beneficial source of iron for greenhouse tomato cultivated in peat substrate was Fe 9 Premium (DTPA) chelate, which resulted in the highest marketable as well as early fruit yield. The average marketable yield for the plants fertilised with the mentioned chelate was significantly higher 
Table 1. Marketable and early yield of 'Merkury' $F_{1}$ greenhouse tomato fruits in relation to the kind of chelates and iron content inpeat substrate $\left(\mathrm{kg} \mathrm{m}^{-2}\right)$

\begin{tabular}{|c|c|c|c|c|c|}
\hline & \multirow{2}{*}{ Kind of Fe fertiliser } & \multicolumn{4}{|c|}{ Fe content in peat substrate $\left(\mathrm{mg} \mathrm{dm}^{-3}\right)$} \\
\hline & & 50 & 75 & 100 & Mean \\
\hline \multirow{7}{*}{ Marketable yield } & Fe 13 Top (EDTA) & 14.64 & 13.33 & 13.35 & 13.77 \\
\hline & Fe 8 Forte (EDTA+HEEDTA) & 14.50 & 14.52 & 14.28 & 14.43 \\
\hline & Librel Fe DP7 (DTPA) & 14.59 & 14.84 & 13.14 & 14.19 \\
\hline & Fe 9 Premium (DTPA) & 14.17 & 14.53 & 15.41 & 14.70 \\
\hline & Mean & 14.48 & 14.30 & 14.04 & 14.27 \\
\hline & Control & & & & 14.02 \\
\hline & \multicolumn{5}{|c|}{$\mathrm{LSD}_{\mathrm{p}=0.05}$ for: fertiliser -0.31 , dose -0.28 , interaction -0.41} \\
\hline \multirow{7}{*}{ Early yield } & Fe 13 Top (EDTA) & 3.50 & 3.67 & 3.76 & 3.64 \\
\hline & Fe 8 Forte (EDTA+HEEDTA) & 3.57 & 3.12 & 3.09 & 3.26 \\
\hline & Librel Fe DP7 (DTPA) & 3.65 & 3.31 & 3.24 & 3.40 \\
\hline & Fe 9 Premium (DTPA) & 3.31 & 3.57 & 4.14 & 3.67 \\
\hline & Mean & 3.51 & 3.42 & 3.56 & 3.50 \\
\hline & Control & & & & 3.13 \\
\hline & \multicolumn{5}{|c|}{$\mathrm{LSD}_{\mathrm{p}=0.05}$ for: fertiliser -0.12 , dose - n.s., interaction -0.17} \\
\hline
\end{tabular}

than the ones obtained with the use of the remaining fertilisers, except for the treatment with Fe 8 Forte as a source of iron. The last one, a blended chelate, is reported equally highly effective at both high and low pH values (Bergman 1992). A significantly lower average marketable yield was recorded after the application of Fe 13 Top chelate, which was even slightly lower than in the control treatment. This finding is not in agreement with the data reported by Gul and Sevgican 1989, and Komosa et al. (2001), who did not find any considerable differences in the yielding of greenhouse tomato grown in rockwool when different chelates were introduced. The diversified yielding recorded in our own investigation, especially in treatments with EDTA chelate as the iron source, could result from a poor availability of iron as the ligand, as it features a high stability only up to pH 6.20 (Sanchez et al. 2005), while at higher $\mathrm{pH}$ values the phenomenon of increased iron retrogradation becomes a fact. During the course of the experiment, the substrate of initial $5.50 \mathrm{pH}$ showed a gradual increase in $\mathrm{pH}$, up to $6.50-6.80$ at the end of the growing period, as a result of plant watering with slightly alkaline water.

Fe fertilisation up to $50 \mathrm{mg} \mathrm{Fe} \mathrm{dm}^{-3}$ in peat substrate contributed to the increase in average marketable fruit yield in comparison to the control treatment, which contained an average of $17.9 \mathrm{mg}$ $\mathrm{Fe} \mathrm{dm}^{-3}$. Increased iron concentration, up to 75 and $100 \mathrm{mg} \mathrm{Fe} \mathrm{dm}^{-3}$, did not bring any further increase in average fruit yield. The only exception was the application of Fe 9 Premium which, at higher contents of this element in the growing medium (up to 75 and $100 \mathrm{mg} \mathrm{Fe} \mathrm{dm}^{-3}$ ), resulted in a systematic and significant increase of marketable fruit yield. The poor efficiency of high $\mathrm{Fe}$ doses in yield increment of vegetables has been observed in some other studies. The research conducted by Kozik at al. (2011) indicated that different sources of Fe did not affect the crop yield of lettuce if applied at rates within 45-220 $\mathrm{mg} \mathrm{Fe} \mathrm{dm}^{-3}$, while Librel Fe (DTPA) even caused some reduction of yield. Loop (1983) found that $50 \mathrm{ppm}$ of iron is needed for maximum biomass yield of such agriculture crops as rape and maize, and 40 ppm for oats.

The highest recorded value regarding average marketable fruit yield, amounting to $15.41 \mathrm{~kg} \mathrm{~m}^{-2}$, was obtained at $100 \mathrm{mg} \mathrm{Fe} \mathrm{dm}^{-3}$ in the growing medium after the afore mentioned chelate application. Introducing $\mathrm{Fe} 8$ Forte and Librel Fe DP7 fertilisers, the highest yields were achieved at $75 \mathrm{mg} \mathrm{Fe} \mathrm{dm}{ }^{-3}$ of peat. In the case of Fe $13 \mathrm{Top}$ chelate, the most satisfactory yielding was recorded at $50 \mathrm{Fe} \mathrm{dm}^{-3}$, yet the increase in $\mathrm{Fe}$ concentration up to 75 and $100 \mathrm{mg} \mathrm{Fe} \mathrm{dm}^{-3}$ of peat did have an effect in the significant decrease in yielding. Chohura et al. (2006) reported similar results for a comparatively long growing period.

Differentiated $\mathrm{Fe}$ fertilisation also influenced the earliness of tomato yielding; however, it was not dependent on Fe content in the growing medium but only on the kind of fertiliser applied. A significantly higher early yield was obtained when 
Table 2. 'Merkury' $F_{1}$ greenhouse tomato fruit composition in relation to the kind of chelate and iron content in peat substrate

\begin{tabular}{|c|c|c|c|c|c|}
\hline & \multirow[b]{2}{*}{ Kind of Fe fertiliser } & \multicolumn{4}{|c|}{ Fe content in peat substrate $\left(\mathrm{mg} \mathrm{dm}^{-3}\right)$} \\
\hline & & 50 & 75 & 100 & Mean \\
\hline \multirow{7}{*}{ Dry mater $(\%)$} & Fe 13 Top (EDTA) & 4.88 & 4.77 & 4.74 & 4.80 \\
\hline & Fe 8 Forte (EDTA+HEEDTA) & 4.75 & 5.03 & 5.04 & 4.94 \\
\hline & Librel Fe DP7 (DTPA) & 4.80 & 5.15 & 4.81 & 4.92 \\
\hline & Fe 9 Premium (DTPA) & 4.78 & 4.70 & 4.64 & 4.71 \\
\hline & Mean & 4.80 & 4.91 & 4.81 & 4.84 \\
\hline & Control & & & & 5.01 \\
\hline & \multicolumn{5}{|c|}{$\mathrm{LSD}_{\mathrm{p}=0.05}$ for: fertiliser -0.31 , dose -0.28 , interaction -0.41} \\
\hline \multirow{7}{*}{$\begin{array}{l}\text { Vitamin C } \\
\text { (mg } 100 \mathrm{~g}^{-1} \text { f.m.) }\end{array}$} & Fe 13 Top (EDTA) & 17.92 & 16.47 & 16.20 & 16.86 \\
\hline & Fe 8 Forte (EDTA+HEEDTA) & 17.47 & 16.15 & 14.15 & 15.92 \\
\hline & Librel Fe DP7 (DTPA) & 16.05 & 15.02 & 17.15 & 16.07 \\
\hline & Fe 9 Premium (DTPA) & 16.15 & 12.71 & 13.55 & 14.14 \\
\hline & Mean & 16.90 & 15.09 & 15.26 & 15.75 \\
\hline & Control & & & & 16.10 \\
\hline & \multicolumn{5}{|c|}{$\mathrm{LSD}_{\mathrm{p}=0.05}$ for: fertiliser -0.12 , dose - n.s., interaction -0.17} \\
\hline \multirow{7}{*}{$\begin{array}{l}\text { Sodium } \\
\text { (mg Na100 g } \text { g }^{-1} \text { f.m.) }\end{array}$} & Fe 13 Top (EDTA) & 1.31 & 1.63 & 1.95 & 1.63 \\
\hline & Fe 8 Forte (EDTA+HEEDTA) & 1.06 & 1.35 & 1.39 & 1.27 \\
\hline & Librel Fe DP7 (DTPA) & 0.99 & 1.25 & 1.02 & 1.09 \\
\hline & Fe 9 Premium (DTPA) & 1.12 & 1.00 & 1.12 & 1.08 \\
\hline & Mean & 1.12 & 1.31 & 1.37 & 1.27 \\
\hline & Control & & & & 0.84 \\
\hline & \multicolumn{5}{|c|}{$\mathrm{LSD}_{\mathrm{p}=0.05}$ for: fertiliser - 0.21, dose - n.s., interaction - n.s. } \\
\hline \multirow{7}{*}{$\begin{array}{l}\text { Nitrates } \\
\left(\mathrm{mg} \mathrm{NO}_{3} \mathrm{~kg}^{-1} \mathrm{f} . \mathrm{m} .\right)\end{array}$} & Fe 13 Top (EDTA) & 34.2 & 41.8 & 35.4 & 37.1 \\
\hline & Fe 8 Forte (EDTA+HEEDTA) & 27.6 & 26.3 & 41.2 & 31.7 \\
\hline & Librel Fe DP7 (DTPA) & 29.3 & 22.7 & 35.6 & 29.2 \\
\hline & Fe 9 Premium (DTPA) & 34.2 & 28.6 & 31.1 & 31.3 \\
\hline & Mean & 31.3 & 29.9 & 35.8 & 32.3 \\
\hline & Control & & & & 31.3 \\
\hline & \multicolumn{5}{|c|}{$\mathrm{LSD}_{\mathrm{p}=0.05}$ for: fertiliser - n.s., dose - n.s., interaction - n.s. } \\
\hline
\end{tabular}

Fe 9 Premium and Fe 13 Top were used. Contrary to the treatment fertilised with Fe 8 Forte and Librel $\mathrm{Fe}$ DP7 chelates, the increase in Fe content in the growing medium with the use of $\mathrm{Fe} 13$ Top and $\mathrm{Fe}$ 9 Premium contributed to a significant increase of the size of the average early yield. However, tomato fruits from the plants fertilised with Fe 13 Top and Fe 9 Premium contained less dry matter than the other ones. The highest content of dry matter $5.10 \%$ - was recorded for fruits from the control treatment. Increased $\mathrm{Fe}$ content in the growing medium affected dry matter content (4.80-4.91\%) to a slight degree on average, contributing to an insignificant decrease in average vitamin $C$ content in fruits. The highest average vitamin $\mathrm{C}$ values were found in tomato fruits from plants fertilised with Fe 13 Top chelate. The values obtained in our own investigation, regarding the amounts of dry matter and vitamin $\mathrm{C}$, were typical for greenhouse tomatoes (Halmann and Kobryń 2002).

The mineral composition of tomato fruits expressed by the content of phosphorus, potassium, magnesium and sodium was generally not affected by the form and rate of Fe chelate fertilisers (Tabs 2-3). The only exception was the increment of $\mathrm{Na}$ content in treatments supplied with $\mathrm{Fe} 13$ Top (EDTA) fertiliser, regardless of the dose of this nutrient. This effect is easy to explain by the contamination of EDTA chelates by sodium and the absence of this element in the other bonding ligands. Phosphorus content was significantly reduced by heavy Fe fertilisation at the rates of 75 and $100 \mathrm{mg}$ 
Table 3. Mineral element content in 'Merkury' $F_{1}$ greenhouse tomato fruits in relation to the kind of chelate and iron concentration in peat substrate ( $\mathrm{mg} 100 \mathrm{~g}^{-1} \mathrm{f} . \mathrm{m}$.)

\begin{tabular}{|c|c|c|c|c|c|}
\hline & \multirow[b]{2}{*}{ Kind of Fe fertiliser } & \multicolumn{4}{|c|}{ Fe content in peat substrate $\left(\mathrm{mg} \mathrm{dm}^{-3}\right)$} \\
\hline & & 50 & 75 & 100 & Mean \\
\hline \multirow{7}{*}{ Phosphorus } & Fe 13 Top (EDTA) & 22.5 & 19.1 & 18.6 & 20.1 \\
\hline & Fe 8 Forte (EDTA+HEEDTA) & 22.1 & 20.4 & 17.3 & 19.9 \\
\hline & Librel Fe DP7 (DTPA) & 23.1 & 21.0 & 21.0 & 21.7 \\
\hline & Fe 9 Premium (DTPA) & 19.9 & 17.6 & 17.6 & 18.4 \\
\hline & Mean & 21.7 & 19.8 & 18.9 & 20.1 \\
\hline & Control & & & & 21.9 \\
\hline & \multicolumn{5}{|c|}{$\mathrm{LSD}_{\mathrm{p}=0.05}$ for: fertiliser - n.s., dose -0.9 , interaction - n.s. } \\
\hline \multirow{7}{*}{ Potassium } & Fe 13 Top (EDTA) & 207 & 215 & 225 & 216 \\
\hline & Fe 8 Forte (EDTA+HEEDTA) & 226 & 201 & 207 & 211 \\
\hline & Librel Fe DP7 (DTPA) & 228 & 233 & 227 & 229 \\
\hline & Fe 9 Premium (DTPA) & 203 & 198 & 186 & 196 \\
\hline & Mean & 216 & 212 & 211 & 213 \\
\hline & Control & & & & 210 \\
\hline & \multicolumn{5}{|c|}{$\mathrm{LSD}_{\mathrm{p}=0.05}$ for: fertiliser - n.s., dose - n.s., interaction - n.s. } \\
\hline \multirow{7}{*}{ Magnesium } & Fe 13 Top (EDTA) & 16.84 & 15.74 & 15.88 & 16.15 \\
\hline & Fe 8 Forte (EDTA+HEEDTA) & 16.63 & 16.10 & 15.88 & 16.20 \\
\hline & Librel Fe DP7 (DTPA) & 16.56 & 17.25 & 17.56 & 17.12 \\
\hline & Fe 9 Premium (DTPA) & 15.30 & 15.28 & 14.15 & 14.91 \\
\hline & Mean & 16.33 & 16.09 & 15.87 & 16.10 \\
\hline & Control & & & & 16.51 \\
\hline & \multicolumn{5}{|c|}{$\mathrm{LSD}_{\mathrm{p}=0.05}$ for: fertiliser - n.s., dose - n.s., interaction - n.s. } \\
\hline \multirow{7}{*}{ Calcium } & Fe 13 Top (EDTA) & 12.20 & 10.73 & 10.48 & 11.14 \\
\hline & Fe 8 Forte (EDTA+HEEDTA) & 11.88 & 11.32 & 12.50 & 11.90 \\
\hline & Librel Fe DP7 (DTPA) & 10.85 & 11.54 & 11.06 & 11.15 \\
\hline & Fe 9 Premium (DTPA) & 10.56 & 10.72 & 10.49 & 10.59 \\
\hline & Mean & 11.37 & 11.08 & 11.13 & 11.19 \\
\hline & Control & & & & 10.01 \\
\hline & \multicolumn{5}{|c|}{$\mathrm{LSD}_{\mathrm{p}=0.05}$ for: fertiliser - n.s., dose - n.s., interaction - n.s. } \\
\hline
\end{tabular}

Fe $\mathrm{dm}^{-3}$. In the literature, the depression effect of high phosphorus (in addition to high $\mathrm{pH}$ ) on iron uptake and utilisation by plants has been reported (Bergman 1992). However, no indication could be found about an adverse effect of iron fertilisation on P uptake. The accumulation of nitrates in tomato fruits was very low - within 22.7-41.8 $\mathrm{mg}$ per $1 \mathrm{~kg}$ fresh weight - and not significantly influenced by the iron nutrition.

\section{CONCLUSIONS}

1. The kind of $\mathrm{Fe}$ chelate applied significantly affected the marketable yield of the 'Merkury' $\mathrm{F}_{1}$ greenhouse tomato cultivar grown in peat substrate. The highest yield was produced by the plants fertilised with Fe 9 Premium, while the lowest one was recorded for Fe 13 Top chelate.

2. Increased $\mathrm{Fe}$ content in the growing medium, from 50 to 75 and $100 \mathrm{mg} \mathrm{Fe} \mathrm{dm}^{-3}$, did not influence the greenhouse tomato marketable yield, except for the treatment where $\mathrm{Fe} 9$ Premium was used, of which a level of $100 \mathrm{mg}$ $\mathrm{Fe} \mathrm{dm}^{-3}$ proved to be the most advantageous for plants.

3. Out of all of the fertilisers introduced to the peat substrate, the highest early yield resulted from Fe 9 Premium and Fe 13 Top chelate application.

4. The factors investigated in the experiment had a negligible effect on tomato fruit composition. The only exception was the increment of $\mathrm{Na}$ content in treatments supplied with Fe 13 Top 
(EDTA) fertiliser, regardless of the dose of this nutrient.

\section{REFERENCES}

Álvarez-Fernández A., Garc'ia-Marco S., Lucena J., 2005. Evaluation of synthetic iron(III)-chelates (EDDHA/Fe3+, EDDHMA/Fe3+ and the novel EDDHSA/Fe3+) to correct iron chlorosis. Europ. J. Agronomy 22: 119-130.

Bergmann W., 1992. Nutritional disorders of plants. Development visual and analytical diagnosis. Gustav Fisher. Verlag. Jena, Stuttgart, New York.

Chohura P., Кoєota E., КoŁota E., 2006: Wpływ chelatów żelazowych Librel Fe-DP7, Pionier Fe 13 i Top 12 na stan odżywienia mikroelementami pomidora szklarniowego $\mathrm{w}$ wełnie mineralnej. Acta Agrophysica 7(3): 549-560.

Chohura P., Koøota E., Komosa A., 2007. The effect of different source of iron on nutritional value of greenhouse tomato fruit grown in peat substrate. Veg. Crops Res. Bull. 67: 55-61.

FERNÁNDEZ V., EBERT G., 2005. Foliar iron fertilization: A critical review. J. Plant Nutr. 28: 2113-2124.

GuerinOt M.L., Yi Y., 1994. Iron, nutritious, noxious, and not readily available. Plant Physiol. 104: 815-820.

Gul A., Sevgican A., 1989. Effect of growing media on glasshouse tomato yield and quality. Acta Hort. 303: 145-150.

Halmann H., Kobryń J., 2002. Fruit quality estimation of two tomato types (Lycopersicon esculentum Mill. and Lycopersicon esculentum var. cerasiforme) grown on rockwool in the glasshouse. Folia Hort. 14(1): 79-86.

Komosa A., Koєota E., Chohura P., 2001. Usefulness of iron chelates for fertilization of greenhouse tomato cultivated in rockwool. Veg. Crops Res. Bull. 55: 35-40.

Komosa A., 2005. Aktualne tendencje w żywieniu roślin warzywnych uprawianych pod osłonami. Zesz. Nauk. AR we Wrocławiu 515: 267-279.

Kozik E., Tyksiński W., Bosiacki M., 2011. A comparison of the efficiency of organic and mineral iron compounds in the greenhouse cultivation of lettuce. J. Elementol. 16(1): 59-68.

Laurie S.H., Tancock N.P., Mcgrath S.P., Sanders J.R., 1991. Influence of complexation on the uptake by plants of iron, manganese, copper and zinc: II. Effect of DTPA in a multi-metal and computer simulation study. J. Exp. Bot., 42: 515-519.

Loop P.L., 1983. Untersuchungenzur Diagnose des Eisen-Versorgungsgrades von Kulturpflanzen. Diss. Agrarw. Fak. Christian-Albert-Univ. Kiel 1983.

Lorenz O.A., MaYnARd D., 1988. Knott's handbook for vegetable growers. $3^{\text {rd }}$ ed. Wiley, New York.
Mills H.A., Jones JR. J., 1996. Plant Analysis Handbook II, MicroMacro Publishing Inc, Athens, GA, USA.

SÁnchez A.S., JuÁrez M., SÁnchez-Andreu J., Jordá J., Bermúdez D., 2005. Use of humic substances and amino acids to enhance iron availability for tomato plants from applications of the chelate FeEDDHA. J. Plant Nutr. 28: 1877-1886.

Schmidt W., Steinbach S., 2000. Sensing iron - a whole plant approach. Ann. Bot. 86: 589-593.

Tiffin L.O., Brown J.C., Holmes R.S., 1960. Chelating agent and plant nutrient interactions affecting the iron nutrition of soybeans. Soil Sci. Soc. Am. J. 24: 120-123.

\section{WPEYW RODZAJU CHELATU Fe NA PLONOWANIE I JAKOŚĆ OWOCÓW POMIDORA SZKLARNIOWEGO}

Streszczenie: W 2-letnim doświadczeniu badano wpływ czterech nawozów chelatowych, różniących się procentową zawartością żelaza oraz rodzajem ligandu jakim skompleksowano ten składnik: Fe 8 Forte (EDTA+HEEDTA), Fe 9 Premium (DTPA), Fe 13 Top (EDTA) i Librel Fe DP7 (DTPA) na plonowanie i jakość owoców pomidora szklarniowego odmiany 'Merkury $\mathrm{F}_{1}$ ' uprawianego w substracie torfowym. Każdy z badanych nawozów był stosowany $\mathrm{w}$ takiej ilości, aby osiagnać zasobność podłoża w żelazo wynoszącą: 50, 75 i $100 \mathrm{mg} \mathrm{Fe} \mathrm{dm}^{-3}$. Średnia zawartość tego składnika w kontroli wynosiła $17,9 \mathrm{mg} \mathrm{Fe} \mathrm{dm}^{-3}$. Pomidory uprawiano od kwietnia do lipca z rozsady sadzonej na stołach. Najwyższy plon handlowy owoców pomidora uzyskano $\mathrm{z}$ roślin nawożonych nawozem Fe 9 Premium (DTPA), a najniższy po zastosowaniu chelatu Top 13 (EDTA). Obydwa te nawozy jako źródła żelaza dla roślin miały taki sam wpływ na wysokość plonu wczesnego pomidora, który był istotnie wyższy po ich zastosowaniu w porównaniu do pozostałych testowanych chelatów. Najlepsze efekty produkcyjne $\mathrm{w}$ plenności i wczesności plonowania uzyskano przy zasobności podłoża wynoszącej $50 \mathrm{mg} \mathrm{Fe} \mathrm{dm}^{-3}$. Rodzaj nawozu chelatowego i dawka żelaza miały niewielki wpływ na skład chemiczny owoców. Wyjątkiem były zawartość witaminy $\mathrm{C}$, która uległa istotnemu obniżeniu po zastosowaniu $\mathrm{Fe} 9$ Premium oraz wzrost koncentracji sodu po zastosowaniu $\mathrm{Fe} 13$ Top. Zwiększenie zawartości żelaza w podłożu do 75 i $100 \mathrm{mg} \mathrm{Fe} \mathrm{dm}^{-3}$ ograniczało istotnie zawartość fosforu w owocach.

Received February 9, 2012; accepted May 28, 2012 